\title{
O letramento e o brincar em processos de socialização na educação infantil
} brincadeiras diferentes*

\author{
VANESSA FERRAZ ALMEIDA NEVES \\ Universidade Federal de Minas Gerais, Belo Horizonte, MG, Brasil \\ MARIA LÚCIA CASTANHEIRA \\ Universidade Federal de Minas Gerais, Belo Horizonte, MG, Brasil \\ MARIA CRISTINA SOARES GOUVÊA \\ Universidade Federal de Minas Gerais, Belo Horizonte, MG, Brasil
}

\section{RESUMO}

O objetivo do presente texto é examinar, com base na análise do cotidiano de uma escola pública de educação infantil em Belo Horizonte, MG, os significados do ler, escrever e brincar para crianças pequenas. Este estudo situa-se no contexto das discussões sobre o lugar do letramento e da alfabetização na educação infantil que foram intensificadas com o estabelecimento da obrigatoriedade do ensino fundamental de nove anos (leis federais n. 11.114/2005 e n. 11.274/2006 e emenda constitucional n.59/2009). A análise apresentada faz parte de estudo mais abrangente, desenvolvido tomando-se por base a abordagem etnográfica interacional (Green; Dixon; Zaharlick, 2005), a abordagem interpretativa da sociologia da infância (Corsaro, 2005) e a perspectiva social do letramento (Castanheira; Green; Dixon, 2007; Soares, 1999; Street, 1984). Tal análise nos permite demonstrar a possibilidade da integração do letramento e do brincar na educação infantil.

\section{PALAVRAS-CHAVE}

brincar; letramento; educação infantil; etnografia interacional.

* A primeira versão deste texto foi apresentada na 35a Reunião Anual da Associação Nacional de Pós-Graduação em Educação (ANPEd), em 2011. As autoras agradecem o apoio da prefeitura de Belo Horizonte/MG, da Fundação de Amparo à Pesquisa de Minas Gerais (FAPEMIG) e do Conselho Nacional de Desenvolvimento Científico e Tecnológico (CNPq). 


\title{
LITERACY AND PLAY IN SOCIALIZATION PROCESSES IN EARLY CHILDHOOD EDUCATION: PLAYING DIFFERENTLY
}

\begin{abstract}
In this paper we aim to analyze the meanings of reading, writing and playing for children on a daily basis in early childhood education in a public school in Belo Horizonte in Brazil. This research is based on discussions about the role of literacy in early childhood education that have instensified with the establishment of nine years of compulsory elementary education (federal laws n. 11.114/2005 and n. 11.274/2006 and constitutional amendment n. 59/2009). Our analysis is part of a broader research, developed from and based on an interactional ethnography approach (Green; Dixon; Zarlick, 2005), an interpretative approach to the sociology of childhood (Corsaro, 2005) and a social literacy perspective (Castanheira; Green; Dixon, 2007; Soares, 1999; Street, 1984). Such analysis allows us to demonstrate the possibility of integration between literacy and play in early childhood education.
\end{abstract}

KEYWORDS

play; literacy; early childhood education; interactional ethnography.

\section{EL LETRAMIENTO Y EL JUEGO EN LOS PROCESOS DE SOCIALIZACIÓN EN LA EDUCACIÓN INFANTIL: JUGAR DE MANERA DIFERENTE}

\section{RESUMEN}

En este trabajo se pretende analizar los significados de la lectura, escritura y juegos para niños en base al análisis de la rutina en una escuela de educación infantil pública en Belo Horizonte (Brasil). Esta investigación está relacionada con los debates sobre el letramiento y la alfabetización en la educación infantil, que fueron intensificados debido a la obligatoriedad de nueve años en la educación primaria de Brasil (leyes federales n.11.114/2005 y n. 11.274/2006 y la enmienda constitucional n. 59/2009). Nuestro análisis forma parte de una investigación más amplia, desarrollada a través de un enfoque etnográfico interaccional (Green; Dixon; Zarlick, 2005), la perspectiva interpretativa de la sociología de la infancia (Corsaro, 2005), y la perspectiva social del letramiento (Castanheira; Green; Dixon, 2007; Soares, 1999; Street, 1984). Este análisis nos permite demostrar la posibilidad de integración entre el letramiento y el juego en educación infantil.

\section{PALABRAS CLAVE}

jugar; letramiento; educación infantil; etnografía interaccional. 


\section{INTRODUÇÃO}

Que lugar a escrita ocupa ou deve ocupar na vida de crianças, dentro e fora de instituições educacionais? A importância dessa questão fica evidente ao observarmos que ela esteve no centro das discussões sobre a especificidade da educação infantil diante do ensino fundamental ao longo das últimas décadas e é, novamente, ponto polêmico em discussões realimentadas pelas leis federais n. 11.114/2005 e n. 11.274/2006 e pela emenda constitucional n. 59/2009, que instituíram o ensino fundamental de nove anos como obrigatório em todo o território nacional. Essa nova configuração da educação básica provoca inúmeros debates entre acadêmicos, gestores, professores e famílias, salientando algumas tensões no campo da educação infantil (Brandão; Rosa, 2010; Brasil, 2009; Campos, 2009, por exemplo).

Nesse contexto de mudanças, um dos principais pontos de discussão centra-se nas relações entre o brincar - considerado um dos eixos centrais no trabalho com a criança pequena - e a construção do conhecimento na educação infantil, particularmente no tocante ao letramento e à apropriação da linguagem escrita, considerada responsabilidade do ensino fundamental. Kramer (2010) denuncia a escassez de trabalhos que examinem o lugar da leitura e da escrita na educação infantil. Tal escassez reafirma certas convicções acerca das finalidades desse nível de ensino e de suas diferenças em relação às práticas pedagógicas no ensino fundamental. É nesse espaço de diferenciação, algumas vezes configurado como distanciamento, que podem ser observadas descontinuidades no processo de escolarização das crianças, seja quando passam da educação infantil para o ensino fundamental (Moss, 2008; Neves; Gouvêa; Castanheira, 2011; Nogueira, 2011, por exemplo), seja no tocante às experiências desse grupo geracional com a escrita dentro e fora da escola (Castanheira, 1991; Gilmore; Glatthorn, 1987; Heath, 1983).

Corsino (2005) caracteriza uma das maneiras como tal descontinuidade pode se configurar ao analisar o trabalho desenvolvido com a escrita na educação infantil na cidade do Rio de Janeiro. Segundo ela, embora gestores e educadores dessa rede municipal de ensino reconheçam a importância do trabalho com a língua escrita nesse segmento, as atividades desenvolvidas com as crianças continuam a privilegiar cópias do alfabeto ou trabalhos de coordenação motora, objetivando uma suposta preparação para o ensino fundamental.

Essa perspectiva de trabalho implica uma ruptura com os modos como as crianças interagem com a escrita fora da escola, destituindo-a de significados pessoais e sociais, e dificulta, portanto, que as atividades desenvolvidas no espaço escolar envolvam a ludicidade, característica fundamental dessa fase do desenvolvimento infantil (Corsaro, 1992, 2005; Vigotski, 2008). Essa forma de abordagem de ensino da escrita, conforme caracterizada por Corsino, corresponde ao que foi denominado como modelo autônomo de letramento (Street, 1984). Baptista (2010), apontando os equívocos nas práticas de alfabetização e letramento, tanto na educação infantil como no ensino fundamental, afirma que é possível e necessário o trabalho com a língua escrita que respeite o direito social da criança à infância.

Tensões e problemas como os identificados anteriormente têm sido continuamente discutidos ao longo da história da educação brasileira (Barbosa, 2007; 
Borba, 2005; Campos, 1999; Castanheira, 1991, entre outros). Sem dúvida, examinar e debater o lugar que a escrita ocupa ou deve ocupar na vida das crianças dentro e fora da escola é tema fundamental para o campo da educação básica, e essa discussão precisa ser feita também para a educação infantil. Parece-nos, entretanto, que há necessidade de que tal problemática seja examinada também pela perspectiva das crianças, o que tem recebido pouca atenção até agora.

Dessa forma, perguntamos: Como as crianças lidam com as relações entre o brincar e a aprendizagem da escrita no cotidiano da educação infantil? A importância de se explorar essa temática pelo ponto de vista das crianças assenta-se no reconhecimento da centralidade das práticas sociais do grupo geracional para seus processos de socialização e de construção de conhecimentos, que, no caso de crianças pequenas, são, sabidamente, marcadas pela ludicidade característica da cultura de pares (Corsaro, 2005; Corsaro; Molinari, 2005).

Neste artigo, examinaremos essa questão valendo-nos da análise de dados que compõem o banco de dados de um estudo de caso de natureza etnográfica, realizado em uma turma de educação infantil da rede municipal de ensino de Belo Horizonte, MG. O estudo teve como objetivo geral, ao acompanhar o processo de passagem de um grupo de crianças da escola de educação infantil para a escola de ensino fundamental, conhecer como se dão os processos de socialização e aprendizagem das crianças nas salas de aula desses dois segmentos de ensino.

Para tanto, examinamos como os participantes dos grupos observados utilizavam e produziam recursos institucionais (por exemplo, tempo, espaço, artefatos culturais) ao desenvolverem suas atividades cotidianas. Tal exame indagou quem poderia fazer o que, com quem, como, quando, onde e com quais propósitos e consequências para a construção de oportunidades de aprendizagem para o indivíduo e para o grupo (Castanheira et al., 2001; Green; Dixon; Zaharlick, 2005). Neste texto, focalizaremos os dados pertinentes à educação infantil para examinar se e como as práticas de letramento se relacionam com o brincar, como as crianças lidam com esses aspectos nesse contexto, e para compreender os significados do brincar, ler e escrever para esse grupo.

Este texto está estruturado em quatro seções. Na primeira delas, articulamos os conceitos de letramento, brincar e cultura de pares orientadores da análise que se apresenta a seguir. Na segunda seção, apresentamos o percurso teórico-metodológico da pesquisa, o que nos permite situar o evento "Brincadeiras diferentes" no contexto das práticas do grupo investigado. Continuando, analisaremos esse evento apresentando-o como um caso expressivo (telling case, como proposto por Mitchell, 1984). Finalmente, concluímos o artigo examinando implicações de nossa análise para as discussões recentes sobre o lugar do letramento na educação infantil.

\section{LETRAMENTO, O BRINCAR E A CULTURA DE PARES}

Ao examinarmos o cotidiano de uma turma de educação infantil, observamos que seus participantes, professora e crianças, estabeleciam uma estreita relação entre o brincar e o letramento. Consideramos fundamental, portanto, articular esses conceitos. O letramento, como já extensivamente discutido por vários autores, é 
mais que a habilidade de ler e escrever (Castanheira; Green; Dixon, 2007; Heath, 1983; Soares, 1999; Street, 1984) e deve ser compreendido como prática social que envolve os sujeitos nos diversos usos dos símbolos gráficos, desenhos e palavras escritas (Kress, 1997). O contexto histórico-cultural em que a linguagem escrita está inserida entrelaça-se com os sentidos dos textos produzidos, bem como com as relações que os sujeitos estabelecem com esses textos e entre si.

Corsaro e Nelson (2003, p. 210-211, tradução nossa) argumentam que

enquanto a cultura adulta da qual uma criança pequena faz parte tem um papel fundamental no seu processo de tornar-se letrado, outras crianças e as culturas de pares nas quais elas participam são igualmente importantes tanto para o processo de letramento quanto para a socialização.

A cultura de pares é entendida como as atividades, as rotinas, os artefatos, os valores e interesses construídos e compartilhados pelo grupo geracional na interação social (Corsaro, 2005). Evidencia-se, assim, o protagonismo nas ações das crianças no espaço da sala de aula ao negociarem com as professoras o processo de socialização e de aprendizagem. $\mathrm{O}$ interesse a respeito da linguagem escrita e suas atividades de letramento é interpretado como maneira de as crianças entenderem e se apropriarem da cultura na qual estão imersas.

O brincar é considerado a forma privilegiada de participação das crianças na cultura desde a mais tenra idade. Wajskop (1995, p. 66), ao discutir a temática do brincar na educação infantil por uma perspectiva sociocultural, destaca que o brincar envolve a imaginação, a imitação e a regra, e "define-se por uma maneira que as crianças têm para interpretar e assimilar o mundo, os objetos, a cultura, as relações e os afetos das pessoas". Essa forma de participação, por meio do processo definido por Corsaro (2005) como reprodução interpretativa, permite que as crianças afirmem-se e também se diferenciem do mundo social, em um processo de construção de suas identidades intimamente relacionado à produção da cultura de pares. Tais processos são, ao mesmo tempo, individuais e coletivos (Gaskins; Miller; Corsaro, 1992).

Um elemento fundamental da teoria da reprodução interpretativa refere-se à natureza reprodutiva e criativa do processo de tornar-se um membro da cultura. Para Corsaro (1992), a atuação ativa, seletiva e criativa das crianças reproduz e, simultaneamente, provoca mudanças na cultura da qual se tornam membros. Além disso, esse autor enfatiza o papel central ocupado pela linguagem e pelas rotinas culturais nos processos de socialização das crianças, uma vez que é por meio da linguagem e das rotinas culturais que as crianças passam a compreender diferentes elementos do mundo em que vivem, apropriam-se e negociam entre si e com os adultos os significados que atribuem as esses elementos (por exemplo, a escrita). Para Corsaro (2005), é a natureza repetitiva das rotinas que proporciona às crianças a possibilidade da reprodução interpretativa de significados atribuídos a elementos da cultura de seu grupo e a posiciona como um membro daquela cultura. Assim, a participação das crianças em uma sala de aula ocorre com e por meio da 
interpretação tecida discursivamente por aquele grupo acerca dos acontecimentos cotidianos (Corsaro, 2005; Hicks, 1995).

$\mathrm{Na}$ educação infantil, assim como ocorre em diferentes contextos sociais, as oportunidades de aprendizagem da leitura e da escrita são construídas por meio de práticas de letramento localmente desenvolvidas por participantes de um determinado grupo social (Castanheira et al., 2001; Cook-Gumperz, 1991; Tuyay et al., 1995). Todavia, contextos mais distantes, como as esferas em que se definem as políticas educacionais e onde se realizam os debates acadêmicos, igualmente impactam os possíveis usos da escrita nas salas de aula. Dessa forma, as interações entre os sujeitos no contexto local são negociadas em relação a contextos globais.

Nesse sentido, Street (2003, p. 80, tradução nossa) afirma que "os resultados dos encontros local-global acerca do letramento são sempre um novo híbrido, em vez de uma versão única de um ou outro". A pergunta que se apresenta, então, relaciona-se a esse novo híbrido no contexto específico da sala de aula investigada, ou seja, como as discussões correntes a respeito do lugar do brincar e da aprendizagem da escrita na educação infantil foram sendo localmente reconstruídas e significadas pelos participantes da turma investigada durante o ano de 2008?

Conforme demonstraremos a seguir, as fronteiras entre as práticas de letramento e o brincar foram sendo redefinidas ao longo das interações estabelecidas no dia a dia da escola de educação infantil. Pode-se argumentar que as crianças e a professora transformaram momentos de brincadeiras em eventos de letramento (Heath, 1983) e, assim, constituíram o que Street (2003) denominou de um híbrido entre a cultura local e a global, no que se refere ao entendimento do lugar do brincar e da aprendizagem da leitura e da escrita na educação infantil.

\section{PERCURSO TEÓRICO-METODOLÓGICO}

O objetivo geral da pesquisa na qual a presente análise insere-se foi o de acompanhar o processo de passagem de crianças da escola de educação infantil para a escola de ensino fundamental e conhecer como, na sala de aula, as crianças e professoras utilizaram o tempo e os espaços para definir como, com quem, quando e onde desenvolveriam suas atividades e quais as consequências dessas atividades para o que as crianças poderiam aprender nesses espaços institucionais. Para isso, realizamos um estudo de caso de natureza etnográfica sobre como essas crianças, oriundas de famílias de baixa renda, morando em áreas de favelas, vivenciaram a transição de uma escola de educação infantil para uma escola de ensino fundamental em duas instituições da rede municipal de ensino de Belo Horizonte. Neste texto, focalizaremos os dados pertinentes à educação infantil para examinar se e como as práticas de letramento relacionaram-se com o brincar, de que maneira as crianças conseguiram lidar com esses aspectos nesse contexto e compreender os significados do brincar, ler e escrever para esse grupo.

Ao longo de 2008, acompanhamos uma turma de crianças da educação infantil em suas atividades diárias, três a quatro vezes por semana, quatro horas e meia por dia. Essa turma era composta por 21 crianças entre 4 e 5 anos e meio de 
idade, sendo dez meninas e onze meninos. Paula, ${ }^{1}$ a professora da turma, trabalhava nessa escola desde 1997, tendo participado de sua direção durante quatro anos. As crianças também tinham três horas semanais de aulas com Júlia, professora de artes, uma hora semanal de brincadeiras no pátio com a coordenadora da escola e uma hora semanal com a turma de 4 anos. Uma das autoras deste texto inseriu-se no campo de pesquisa como observadora, sentando-se em uma das cadeiras pequenas, disponíveis para as crianças, que estavam dispostas ao redor das mesas presentes na sala de aula. Aos poucos, as crianças passaram a incluí-la nas conversas e brincadeiras. Após algumas semanas de observação, iniciou-se a gravação em vídeo dos acontecimentos da sala de aula. A análise dos dados foi orientada pela abordagem etnográfica interacional, que une princípios teóricos da sociolinguística interacional, da antropologia cultural e da análise crítica do discurso. Esses princípios são explorados na construção de uma lógica de investigação para a entrada em um determinado grupo social e para examinar o que os membros precisam saber, produzir, prever e como agir para participar de maneira apropriada da vida desse grupo (Dixon; Green, 2005).

A seguir, abordaremos as relações entre o brincar e as práticas de letramento desenvolvidas na educação infantil a partir da apresentação de (a) uma caracterização da perspectiva do ensino predominante na escola; (b) um mapeamento dos momentos em que o encontro desses dois aspectos ficou mais evidente no dia a dia do grupo observado e, finalmente, (c) uma análise de como as crianças participaram e responderam às atividades propostas pela professora.

\section{BRINCADEIRAS E PRÁTICAS DE LETRAMENTO: UM ENCONTRO NA PERSPECTIVA DO ENSINO}

O principal objetivo do trabalho da professora Paula, segundo seu depoimento em entrevistas e nossa análise do cotidiano, centrava-se no desenvolvimento das habilidades de socialização das crianças, tais como autonomia, negociação de conflitos, ajuda mútua, construção da história do grupo e sua coesão. Nossas primeiras análises indicaram que o uso do tempo estava organizado principalmente em torno das brincadeiras (entre $26 \%$ e $64 \%$ do tempo total) e das rodas de conversa (entre $5 \%$ e $25 \%$ do tempo total). As escolhas de Paula na organização do tempo e do espaço em sua turma dialogavam com o projeto político pedagógico ${ }^{2}$ da escola, que enfatizava a socialização das crianças por meio de jogos e brincadeiras. O relatório produzido pela professora sobre as atividades desenvolvidas nos meses de maio e junho de 2008 refletem essa perspectiva de trabalho, conforme se pode ver em seguida.

1 O nome dos participantes da pesquisa é fictício.

2 O projeto político pedagógico da escola, datado de 2005, é apresentado em uma "versão em constante alteração". Nesse projeto, fica clara a representação da escola como uma instituição cujos membros estão em processo de reflexão continuada sobre a própria prática. 


\section{Brincadeiras}

Listamos todas as brincadeiras que aprendemos nos três primeiros meses; a cada dia escolhíamos aquelas que faríamos e íamos marcando com um traço; ao final dos meses, realizamos a contagem, descobrindo as brincadeiras que fizemos mais vezes, aquelas que gostaríamos de brincar no segundo semestre e a que tiraríamos da lista; registro da brincadeira de que cada um mais gostou de brincar; fomos à biblioteca e descobrimos livros que falavam sobre brincadeiras; lemos os livros e vimos como cada autor registra as brincadeiras. É importante para a criança saber que pode pesquisar diversos assuntos nos livros da biblioteca e como acontecem os diferentes registros. (Diário de Campo. Relatório Geral dos meses de maio e junho, p. 15)

A análise desse relatório oferece indícios da perspectiva institucional no tratamento do brincar e das práticas de letramento que iam se estabelecendo. Por um lado, a primeira sentença do relatório deixa claro que as brincadeiras são objeto de ensino e de aprendizagem, uma vez que são descritas como "brincadeiras que aprendemos". Dessa forma, não se tratam aí de brincadeiras iniciadas e desenvolvidas pelas crianças nos momentos de interação livre entre pares. Por outro lado, mediante a análise desse relatório, podemos ver também que a escrita esteve presente, embora não tivesse sido privilegiada no projeto político pedagógico da escola, tendo os participantes do grupo, por exemplo, produzido uma lista das brincadeiras que aprenderam e de que mais gostaram. Além disso, a professora e os alunos exploraram como diferentes autores retrataram as brincadeiras em suas narrativas ao lerem os livros encontrados na biblioteca da escola. Ademais, a comparação desse relato com o que se observava no dia a dia da escola permitiu reconhecer a intencionalidade educativa dos momentos de brincadeira, bem como suas relações com as rodas de conversa.

Durante as rodas de conversa, os participantes conversavam sobre as experiências vividas pelo grupo e, nesses momentos, os alunos podiam observar o registro escrito dessas conversas feito pela professora em grandes folhas de papel pardo. As rodas de conversa, portanto, constituíram o contexto no qual as crianças podiam vivenciar e compreender o papel social da escrita, fosse no registro de aspectos das conversas sobre as experiências do grupo, fosse na organização das atividades realizadas. O conjunto dessas atividades em torno do tema "brincadeiras" demonstra como estas, ao serem repetidas várias vezes e ao serem tema de conversas e registro, tornaram-se objeto de conhecimento a ser apropriado pelas crianças, integrando-se, dessa maneira particular, à rotina cultural do grupo investigado.

A Figura 1 apresenta cópia de atividade realizada pelos alunos e fornece outros elementos para a compreensão de como as relações entre o brincar e as práticas de letramento foram sendo reconstruídas localmente pelos participantes do grupo observado e de como, por meio dessa reconstrução, a escrita assumiu significados particulares nesse contexto institucional.

$\mathrm{Na}$ Figura 1 temos a atividade que foi realizada por uma das alunas, Marcela. Nela identificamos dois "comandos da atividade". Primeiro temos a frase "Brincadeiras que aprendemos", seguida de uma lista que inclui o nome de nove 


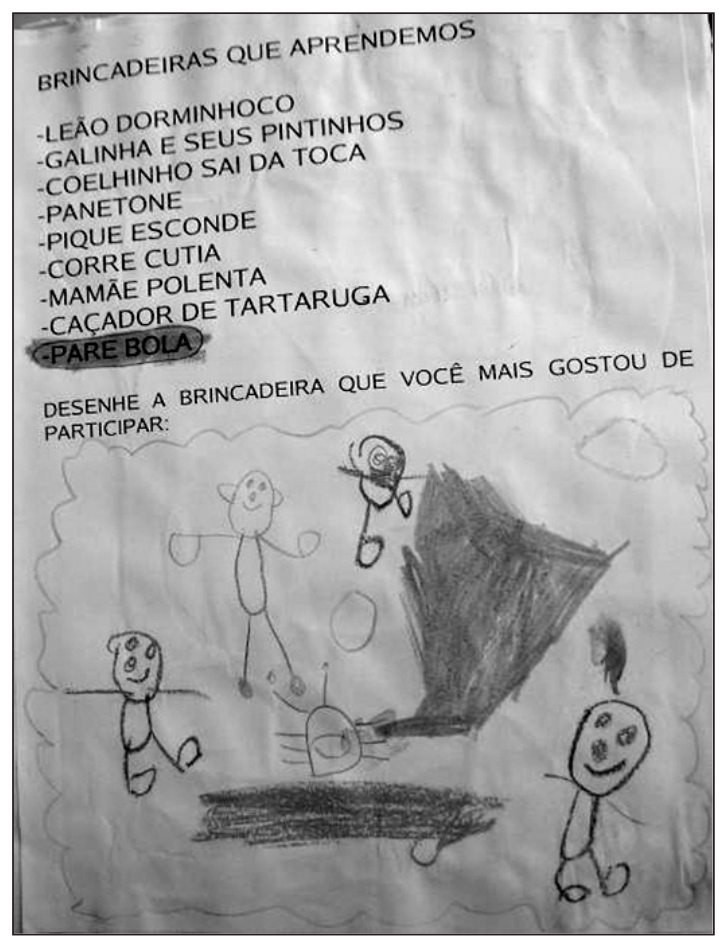

Figura 1 - Atividade escrita sobre brincadeiras realizada por Marcela. Fonte: Banco de dados da pesquisa.

Elaboração das autoras.

brincadeiras. Depois a frase "Desenhe a brincadeira que você mais gostou de participar”, e, finalmente, o espaço em branco a ser preenchido pela criança com seu desenho.

Um dos aspectos que chama atenção é a concisão dessas duas frases. Essa concisão parece ter origem e ser justificada pela contiguidade da proposta/exercício com o contexto em que esta seria desenvolvida. É importante lembrar que, como as crianças ainda não sabiam ler, caberia à professora ler e explicar-lhes o que deveriam fazer. Na primeira frase, "Brincadeira que aprendemos", por exemplo, não se registra como a criança deveria indicar a brincadeira de que mais gostou. No entanto, a professora, após ler o nome das brincadeiras listadas para e com os alunos, verbalizou o que eles deveriam fazer: colorir na lista apresentada a brincadeira de que mais gostava.

$\mathrm{Na}$ Figura 1 podemos ver que a criança marcou pare bola. No comando da segunda atividade, utiliza-se o modo imperativo (desenhe) e orientam-se as crianças a desenharem aquela brincadeira da qual mais gostaram de participar. Embora houvesse relação entre a primeira e a segunda atividade, essa relação não é explicitada no comando escrito da atividade entregue às crianças. 
Nesse sentido, a ausência de referência escrita à listagem anterior e o uso do verbo participar também implicam a necessidade de que a relação entre a primeira e a segunda atividade e o que deveria ser feito pelas crianças fossem explicitados oralmente pela professora. Assim, o modo imperativo utilizado para dar destaque à ação que deveria ser realizada pela criança (desenhe) pode ser visto como evidência da interdependência entre a proposta e o contexto interacional em que esta seria realizada. A escrita começa, então, a assumir uma forma "escolarizada" na educação infantil, servindo a propósitos particulares, articulada ao processo de socialização das crianças, por sua vez, organizado em torno da escolarização das brincadeiras a serem aprendidas.

Entendemos aqui que o processo de escolarização das crianças implica tanto a construção da cultura de pares (Corsaro, 2005) e a apropriação das rotinas e normas escolares (Faria Filho et al., 2004) quanto o processo de construção da identidade das crianças. Esse processo implica, entre outros aspectos, a construção das formas de participação no grupo e da posição social de aluno (Packer; Goicoechea, 2000). Assim, no caso da turma investigada, tornar-se aluno implicou aprender as regras e as formas de participação em diversas brincadeiras ao longo do ano, bem como tomar essas brincadeiras como objeto de aprendizagem e registro em atividades escolares.

Continuando o processo investigativo, outras questões foram formuladas: Como as interações entre os sujeitos aconteceram nos momentos de brincadeiras e nas rodas? Como os sujeitos posicionaram-se e foram posicionados? Para responder a essas questões, na próxima seção focalizaremos o evento "Brincadeiras diferentes", ocorrido no dia 18 de agosto de 2008. A escolha desse evento em particular considerou seu potencial expressivo, ou seja, o que tal análise nos possibilitaria compreender sobre os significados do brincar e do letramento para o grupo observado. Esse evento relaciona-se com outros eventos de letramento que ocorreram ao longo do ano, como ilustrado na Figura 2. Nessa figura, com base nas anotações no diário de campo, classificamos os eventos entre aqueles iniciados pela professora e aqueles iniciados pelas crianças. A seguir, dentro de cada uma dessas categorias, organizamos os eventos em grupos e apresentamos alguns exemplos significativos. Tal classificação nos permite situar o evento "Brincadeiras diferentes" em relação ao contexto de letramento daquela sala de aula.

Conforme se vê na Figura 2, de um lado, os eventos de letramento iniciados pela professora centraram-se, em sua maioria, na leitura (leitura de histórias, idas à biblioteca escolar, marcar nome de brincadeira), posicionando as crianças como leitoras naquele contexto. Ademais, a análise de nossas observações ao longo do ano indicou que não houve uma proposta de reflexão sistematizada sobre o sistema de escrita alfabética por meio do ato de escrever por parte da professora. ${ }^{4}$ Por outro

3 O conceito de evento é entendido como o "conjunto de atividades delimitado interacionalmente em torno de um tema comum num dia específico" (Castanheira, 2004).

4 Em estudo desenvolvido por Gerde, Bingham e Wasik (2012), contemplando um largo número de escolas infantis americanas, o mesmo foi observado: a escrita foi não apenas secundarizada, mas muitas vezes não foi observada sua presença nas práticas de letramento, que ficavam restritas às atividades de leitura. 


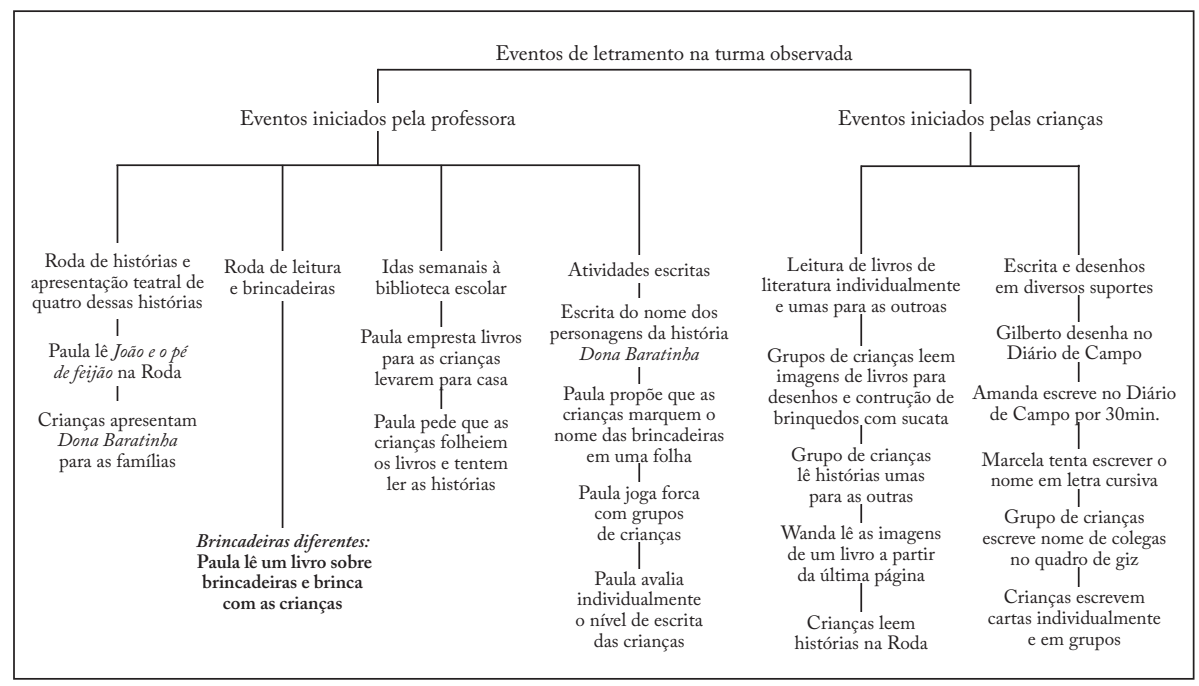

Figura 2 - Classificação dos eventos de letramento na turma observada ao longo de 2008.

Fonte: Banco de dados da pesquisa.

Elaboração das autoras.

lado, os eventos iniciados pelas crianças, além de envolverem a leitura, trazem para o centro da atenção dos participantes a atividade de escrita (por exemplo, as crianças escrevem e desenham em diversos suportes), demonstrando, assim, um grande interesse tanto pela leitura quanto pela escrita. Tal interesse foi manifestado e concretizado no âmbito da cultura de pares daquela turma. Observou-se, então, que, ao brincar, as crianças incorporaram a leitura e a escrita em seus jogos, explorando ativamente os usos, as funções e os significados da escrita, desafiando ou desconstruindo a dicotomia entre o aprender e o brincar implicada nas discussões sobre as especificidades da educação infantil e do ensino fundamental e na realização de um trabalho descontextualizado com a escrita.

No Quadro 1 apresentamos os eventos do dia 18 de agosto de 2008 para situar o evento "Brincadeiras diferentes" 5 no fluxo das atividades desenvolvidas pelo grupo nesse dia e em outros dias do ano. Um mapa de evento é produzido a partir da análise retrospectiva da ação dos participantes de um grupo ao longo do tempo. Tal análise permitiu traçar as ações dos sujeitos no processo de se tornarem membros da cultura de pares e dessa turma da educação infantil.

Conforme representado no Quadro 1, os participantes do grupo observado realizaram ações variadas ao longo desse dia. Essas ações relacionavam-se ao cuidado pessoal, ao uso e organização de materiais (por exemplo, brinquedos, agendas e cadernos) e a atividades pedagógicas propostas pelas professoras.

5 O evento foi nomeado em razão do comentário feito pela professora de que realizariam "brincadeiras diferentes" no pátio. Dessa forma, essa nomeação busca expressar uma perspectiva êmica. 
Quadro 1 - Mapa de eventos - 18 de agosto de 2008

\begin{tabular}{|c|c|c|c|}
\hline Hora & Eventos & Subeventos & Comentários \\
\hline $7 \mathrm{~h}$ & $\begin{array}{l}\text { Entrada: Todas as crianças } \\
\text { da escola, sentadas em uma } \\
\text { grande roda, cantam com } \\
\text { as professoras (pátio). }\end{array}$ & & $\begin{array}{l}\text { A roda no momento } \\
\text { de entrada constituiu- } \\
\text { se em rotina cultural } \\
\text { da escola observada. }\end{array}$ \\
\hline $7 \mathrm{~h} 20$ & $\begin{array}{l}\text { As crianças colocam a } \\
\text { agenda e o caderno na } \\
\text { mesa (sala de aula). }\end{array}$ & & \\
\hline \multirow[b]{2}{*}{$7 \mathrm{~h} 31$} & \multirow[b]{2}{*}{ Roda (oficina de artes). } & $\begin{array}{l}\text { O que vocês fizeram } \\
\text { no feriado? }\end{array}$ & \multirow{2}{*}{$\begin{array}{l}\text { As crianças estavam com } \\
\text { a professora Júlia, que } \\
\text { desenvolveu ao longo do ano } \\
\text { um projeto sobre artistas } \\
\text { plásticos brasileiros. } \\
\text { Foram constantes as } \\
\text { conversas sobre as } \\
\text { aulas anteriores. }\end{array}$} \\
\hline & & A vida de Guignard. & \\
\hline \multirow{2}{*}{$7 \mathrm{~h} 51$} & \multirow{2}{*}{$\begin{array}{l}\text { Pintura das mãos } \\
\text { (oficina de artes). }\end{array}$} & $\begin{array}{l}\text { Conversa sobre a } \\
\text { aula anterior. }\end{array}$ & \\
\hline & & $\begin{array}{l}\text { Pintura de impressão } \\
\text { das mãos no caderno. }\end{array}$ & \\
\hline \multirow[t]{2}{*}{$8 \mathrm{~h} 14$} & \multirow{2}{*}{$\begin{array}{l}\text { Brincadeiras livres } \\
\text { (oficina de artes). }\end{array}$} & $\begin{array}{l}\text { As crianças brincam } \\
\text { entre si e com os } \\
\text { brinquedos disponíveis. }\end{array}$ & \\
\hline & & $\begin{array}{l}\text { Algumas crianças fazem a } \\
\text { pintura da aula anterior. }\end{array}$ & \\
\hline $8 \mathrm{~h} 58$ & $\begin{array}{l}\text { Guardando os brinquedos } \\
\text { (oficina de artes). }\end{array}$ & & $\begin{array}{l}\text { As duas professoras da turma } \\
\text { rotineiramente pediam a } \\
\text { participação das crianças na } \\
\text { organização do ambiente. }\end{array}$ \\
\hline $9 \mathrm{~h} 03$ & Recreio (pátio). & & \\
\hline $9 \mathrm{~h} 35$ & Merenda (cantina). & & \\
\hline $10 \mathrm{~h} 05$ & Escovando os dentes. & & \\
\hline \multirow[t]{2}{*}{$10 \mathrm{~h} 10$} & Roda (sala de aula). & Calendário & $\begin{array}{l}\text { A professora Paula } \\
\text { comenta que a turma } \\
\text { realizará, no pátio, } \\
\text { "brincadeiras diferentes". }\end{array}$ \\
\hline & & Chamada & \\
\hline $10 \mathrm{~h} 27$ & $\begin{array}{l}\text { Organizando os materiais } \\
\text { (sala de aula). }\end{array}$ & & \\
\hline $10 \mathrm{~h} 34$ & Fila para ir para o pátio. & & $\begin{array}{l}\text { A fila aconteceu raras } \\
\text { vezes ao longo do ano. }\end{array}$ \\
\hline
\end{tabular}

(continua...) 
(...continuação)

\begin{tabular}{|c|c|c|c|}
\hline Hora & Eventos & Subeventos & Comentários \\
\hline \multirow{7}{*}{$10 \mathrm{~h} 40$} & \multirow{7}{*}{$\begin{array}{l}\text { Brincadeiras } \\
\text { diferentes (pátio). }\end{array}$} & $\begin{array}{l}\text { Roda 1: Leitura } \\
\text { Livro: Alerta 1, 2, } 3\end{array}$ & \multirow{7}{*}{$\begin{array}{l}\text { Paula ensinou novas } \\
\text { brincadeiras para a turma, } \\
\text { baseando-se em um livro que } \\
\text { pegou na biblioteca com as } \\
\text { crianças na semana anterior. }\end{array}$} \\
\hline & & Brincadeira 1: Alerta 1,2, 3 & \\
\hline & & $\begin{array}{l}\text { Roda 2: Leitura } \\
\text { Livro: Acorda, Senhor Urso }\end{array}$ & \\
\hline & & $\begin{array}{l}\text { Brincadeira 2: Acorda, } \\
\text { Senhor Urso }\end{array}$ & \\
\hline & & $\begin{array}{l}\text { Roda 3: Leitura } \\
\text { Livro: Cabra-cega }\end{array}$ & \\
\hline & & Brincadeira 3: Cabra-cega & \\
\hline & & $\begin{array}{l}\text { Roda 4: Avaliação } \\
\text { das brincadeiras }\end{array}$ & \\
\hline $11 \mathrm{~h} 10$ & Saída (sala de aula). & & \\
\hline
\end{tabular}

Fonte: Banco de dados da pesquisa.

Elaboração das autoras.

Os participantes tomaram parte de atividades como membros da escola (entrada), como participantes da oficina de artes (roda e pintura das mãos), como membros de grupos de pares (brincadeiras livres na oficina de artes), como alunos da professora Paula (calendário, fila para ir ao pátio ou brincadeiras diferentes). Os comentários contidos no Quadro 1 indicam que essas ações e atividades vinculavam-se a procedimentos rotineiros (por exemplo, as professoras pediam a participação das crianças na organização do ambiente) ou a um ciclo de atividades (a professora de artes desenvolveu um projeto sobre artistas plásticos brasileiros ao longo do ano).

Nota-se, ainda, que as crianças puderam brincar livremente e com os brinquedos disponíveis na escola. Além disso, observou-se que eram constantes as conversas entre os participantes (professora e alunos) sobre o que havia acontecido nos dias anteriores. Registrou-se ainda que nesse dia a professora anunciou uma novidade aos alunos durante a atividade diária de atualizarem o calendário da turma (calendário). Com essa ação, a professora indicou aos alunos como a realização das atividades naquele espaço, além de vincularem-se a acontecimentos dos dias anteriores, envolviam projeções para os momentos seguintes.

Ao comparar os eventos desse dia com eventos ocorridos ao longo do ano, verificamos que um dos padrões interacionais recriados e mantidos pelos participantes foi o de conversar sobre as atividades realizadas pelo grupo, tornando-as, assim, objeto de reflexão. A ocorrência rotineira de conversas dessa natureza sugere a continuação das atividades em um todo significativo e reitera oportunidades para as crianças reconhecerem, recriarem, desenvolverem (ou não) formas de participação vistas como apropriadas pelos diversos participantes desse espaço institucional 
(crianças e adultos). Tais aspectos ficarão mais claros com a análise do evento "Brincadeiras diferentes", a seguir.

\section{“BRINCADEIRAS DIFERENTES": BRINCAR LETRANDO... LETRAR BRINCANDO...}

Conforme podemos observar no Quadro 1, após conversar sobre o calendário na sala de aula, Paula foi para o pátio com a turma. Ali, a turma fez uma roda e conversou sobre as brincadeiras que já conhecia. A professora folheou um livro sobre brincadeiras, explicando uma "brincadeira diferente" que o grupo iria aprender. Após a explicação, o grupo levantou-se e brincou. A seguir, nova roda de leitura e conversa, e nova brincadeira. A dinâmica do evento "Brincadeiras diferentes", portanto, desenrolou-se com a alternância entre uma roda de leitura de uma nova brincadeira e a brincadeira em si. $\mathrm{O}$ tempo total destinado a esse evento foi de 26 minutos.

Selecionamos a primeira roda de leitura (Alerta 1, 2, 3), que teve a duração exata de 2 minutos e 3 segundos, que iremos apresentar no Quadro 2. A primeira coluna do quadro destina-se à numeração das unidades de mensagem, ${ }^{6}$ a segunda refere-se às falas e às ações da professora e a terceira registra as falas e ações das crianças. Nos momentos em que foi possível identificar a criança que estava falando, inserimos seu nome. As falas e ações que ocorreram simultaneamente foram colocadas na mesma linha. Na última coluna, tecemos alguns comentários. A gravação foi iniciada no momento em que a professora Paula respondia a Carlos, que solicitou que repetissem uma brincadeira da aula anterior.

Destacamos agora alguns aspectos na análise da Roda 1. Primeiramente, as linhas 40 a 48, que se relacionam à postura corporal das crianças. Paula não chama a atenção do grupo por questão de dispersão ou indisciplina, mas pelo fato de as crianças, em virtude do alto grau de interesse na atividade proposta, impedirem os colegas de observar a leitura que ela realizava. Assim, se, por um lado, não foi exigido que as crianças cruzassem as pernas ou ficassem quietas, por outro, foi esperado que todos tivessem a oportunidade de ver o livro e ouvir a leitura. A ênfase das interações recaiu sobre o objetivo da atividade, aprender uma brincadeira nova que estava escrita em um livro, e não na disciplina das crianças. Nesse momento, a

6 As falas foram transcritas com base nas unidades de mensagem, definidas como a "unidade de significado linguístico demarcada pelos limites da emissão identificados por meio de pistas para contextualização, como a tonicidade, entonação, pausas e gestos" (Gumperz, 1982). Assim, cada pausa ou mudança de entonação marca o início de uma nova unidade de mensagem, o que significa uma nova linha na transcrição ou uma barra (/). Essa forma de transcrição demonstra o que estava disponível para o ouvinte no momento da enunciação, evidenciando os sentidos construídos pelos sujeitos nas interações uns com os outros. As letras maiúsculas indicam a mudança de entonação, os dois pontos (:::) indicam o prolongamento da vogal, e os parêntesis duplos indicam os gestos. 
Quadro 2 - Roda 1 - Leitura: Alerta 1, 2, 3

\begin{tabular}{|c|c|c|c|}
\hline Linhas & Professora & Criança & Comentários \\
\hline 1 & $\begin{array}{l}\text { depois a gente } \\
\text { pode brincar }\end{array}$ & $\begin{array}{l}\text { O grupo olha } \\
\text { para Paula. }\end{array}$ & $\begin{array}{l}1 \text { - Todas as crianças } \\
\text { estão prestando atenção, } \\
\text { sentadas com as pernas } \\
\text { cruzadas. Wanda tem as } \\
\text { pernas esticadas, e Gabriela } \\
\text { senta-se sobre os próprios } \\
\text { joelhos. Lúcio está sentado } \\
\text { de lado, olhando na direção } \\
\text { oposta à professora. } \\
2 \text { - O objeto "livro" chama } \\
\text { muito a atenção das crianças, } \\
\text { não apenas por ser sobre } \\
\text { as novas brincadeiras. Em } \\
\text { outros eventos, as crianças } \\
\text { prestam muita atenção } \\
\text { aos livros e às histórias. }\end{array}$ \\
\hline 2 & & \begin{tabular}{|l|l} 
Carlos fala algo \\
(inaudível)
\end{tabular} & \\
\hline 3 & pois é Carlos & & \\
\hline 4 & vão variar & & \\
\hline 5 & Né, Carlos? & & \\
\hline 6 & $\begin{array}{l}\text { pra gente aprender } \\
\text { outras }\end{array}$ & & \\
\hline 7 & & $\begin{array}{l}\text { ((Jade aponta a capa } \\
\text { do livro)): amarelinha }\end{array}$ & \\
\hline 8 & $e ́$ & & \\
\hline 9 & amarelinha & & \\
\hline 10 & $\begin{array}{l}\text { depois a gente } \\
\text { pode brincar }\end{array}$ & & \\
\hline 11 & $(($ folheia o livro $))$ & $\begin{array}{l}\text { Lúcio, que estava } \\
\text { virado de lado, volta-se } \\
\text { para olhar o livro. }\end{array}$ & \\
\hline 12 & eu achei uma & $\begin{array}{l}\text { Todo o grupo olha } \\
\text { para Paula. }\end{array}$ & \\
\hline 13 & eu achei uma & & \\
\hline 14 & que é muito legal & & $\begin{array}{l}3 \text { - Paula demonstra } \\
\text { interesse pela brincadeira. }\end{array}$ \\
\hline 15 & chama & & \\
\hline 16 & alerta 123 & & \\
\hline 17 & $\begin{array}{l}\text { ((vira o livro para } \\
\text { as crianças) })\end{array}$ & & \\
\hline 18 & & $\begin{array}{l}\text { Criança: vão } \\
\text { brincar dessa? }\end{array}$ & \\
\hline 19 & pois é & & \\
\hline 20 & $\begin{array}{l}\text { ((virando o livro } \\
\text { para si mesma) })\end{array}$ & & $\begin{array}{l}4 \text { - Indicação do uso social } \\
\text { do livro e da escrita. }\end{array}$ \\
\hline 21 & vou ler pra você:::s & & \\
\hline 22 & deixa eu ler & & \\
\hline
\end{tabular}

(continua...) 
(...continuação)

\begin{tabular}{|c|c|c|c|}
\hline Linhas & Professora & Crianças & Comentários \\
\hline 23 & éassim,ó & $(($ Gabriela se ajoelha $))$ & $\begin{array}{l}5 \text { - Gabriela demonstra } \\
\text { interesse em ver as } \\
\text { páginas do livro. }\end{array}$ \\
\hline 24 & $\begin{array}{l}\text { é sentado ((olhando } \\
\text { para Gabriela)) }\end{array}$ & & \\
\hline 25 & & Isadora: tchau, Paula & \\
\hline 26 & Tchau, Isadora & $\begin{array}{l}((\text { Crianças olham } \\
\text { para Isadora }))\end{array}$ & \\
\hline 27 & ó & & \\
\hline 28 & $\begin{array}{l}\text { uma criança } \\
((\text { lendo o livro }))\end{array}$ & & $\begin{array}{l}6 \text { - Crianças observam } \\
\text { a leitura. }\end{array}$ \\
\hline 29 & conta & & \\
\hline 30 & até 5 & & \\
\hline 31 & 12345 & & \\
\hline 32 & $\begin{array}{l}\text { quando terminar } \\
\text { o5 tem que }\end{array}$ & & \\
\hline 33 & falar & & \\
\hline 34 & ALERTA & & \\
\hline 35 & então & \begin{tabular}{|l|} 
((Marcela se \\
aproxima do livro \\
que Paula segura)) \\
((Taís se ajoelha no \\
meio da roda, inclinando \\
o corpo para o chão)) \\
\end{tabular} & $\begin{array}{l}7 \text { - Marcela está interessada } \\
\text { em ver as páginas do livro. }\end{array}$ \\
\hline 36 & $\begin{array}{l}\text { todas as outras } \\
\text { crianças }\end{array}$ & & \\
\hline 37 & $\begin{array}{l}\text { têm que parar } \\
\text { de correr }\end{array}$ & & \\
\hline 38 & e ficar igual estátua & & \\
\hline 39 & & Gilberto: dá licença/ Taís & $\begin{array}{l}8 \text { - Gilberto manteve-se } \\
\text { todo o tempo quieto, } \\
\text { olhando a professora. }\end{array}$ \\
\hline 40 & (inaudível) pessoal & $\begin{array}{l}\text { ((Marcela e Taís voltam } \\
\text { para seus lugares }))\end{array}$ & \\
\hline 41 & $\begin{array}{l}\text { não PODE sair do } \\
\text { lugar ((encostando } \\
\text { a mão no braço } \\
\text { de Marcela)) } \\
\end{array}$ & $\begin{array}{l}((\text { Marcela chega um } \\
\text { pouco mais para trás }))\end{array}$ & \\
\hline 42 & vocês esquecem & & \\
\hline 43 & $\begin{array}{l}\text { que tem outra pessoa } \\
\text { atrás de vocês }\end{array}$ & $\begin{array}{l}\text { ((Lúcio olha para } \\
\text { o próprio tênis e } \\
\text { depois para cima e faz } \\
\text { barulhos: bá-bá)) } \\
\text { ((Wanda olha } \\
\text { para seu tênis })) \\
\end{array}$ & $\begin{array}{l}9 \text { - Quando Paula } \\
\text { chama a atenção das } \\
\text { crianças, Lúcio e Wanda } \\
\text { se dispersam e voltam a } \\
\text { prestar atenção quando } \\
\text { Paula retoma a leitura. } \\
\end{array}$ \\
\hline 44 & que não são só vocês & & \\
\hline
\end{tabular}

(continua...) 
(...continuação)

\begin{tabular}{|c|c|c|c|c|}
\hline Linhas & Professora & \multicolumn{2}{|l|}{ Crianças } & Comentários \\
\hline 45 & $\begin{array}{l}\text { você senta aqui } \\
\text { ((apontando para } \\
\text { o meio da roda)) }\end{array}$ & & & \\
\hline 46 & Marcela & & & \\
\hline 47 & $\begin{array}{l}\text { ela não vê } \\
((\text { encostando a mão } \\
\text { na perna de Júnia }))\end{array}$ & & & \\
\hline 48 & ela fica atrás de você & & & \\
\hline 49 & o pega & $\begin{array}{l}((\text { Taís coloca o } \\
\text { polegar na boca }))\end{array}$ & & \\
\hline 50 & a CRLANÇA & & & \\
\hline 51 & $\begin{array}{l}\text { que falou } 1234 \\
5 \text { éo pegador }\end{array}$ & & & \\
\hline 52 & $\begin{array}{l}\text { ela pode escolher } \\
\text { uma criança }\end{array}$ & & & \\
\hline 53 & dar 3 saltos & & & \\
\hline 54 & $\begin{array}{l}\text { e tentar pegar o } \\
\text { jogador MAIS } \\
\text { próximo }\end{array}$ & & & \\
\hline 55 & $\begin{array}{l}\text { tira o dedo da boca } \\
\text { ((olhando para Taís)) }\end{array}$ & & & \\
\hline 56 & & $\begin{array}{l}\text { ((Taís tira o dedo da } \\
\text { boca e sorri, olhando } \\
\text { para os colegas }))\end{array}$ & & \\
\hline 57 & & Bruno: igual pare bola & & $\begin{array}{l}10 \text { - Bruno relaciona a } \\
\text { brincadeira nova a uma } \\
\text { que o grupo já conhecia. } \\
\text { A primeira resposta de } \\
\text { Paula (não) é retomada } \\
\text { logo a seguir (parece, né?). }\end{array}$ \\
\hline 58 & não & & & \\
\hline 59 & só que é sem bola & & & \\
\hline 60 & Parece, né? & & & \\
\hline 61 & & $\begin{array}{l}\text { ((Bruno balança } \\
\text { a cabeça } \\
\text { afirmativamente }))\end{array}$ & & \\
\hline 62 & $\begin{array}{l}\text { vão tentar } \\
\text { brincar disso? }\end{array}$ & & & $\begin{array}{l}11 \text { - Paula se inclui } \\
\text { na brincadeira. }\end{array}$ \\
\hline 63 & pra ver se é legal? & & & \\
\hline 64 & & Marcela: olha aqui, Paula & $\begin{array}{l}((\text { Crianças } \\
\text { olham para } \\
\text { Marcela }))\end{array}$ & $\begin{array}{l}12 \text { - Marcela compartilha } \\
\text { com Paula uma } \\
\text { brincadeira nova. }\end{array}$ \\
\hline 65 & & sabe aquela (inaudível) & $\begin{array}{l}\text { ((Lúcio vira } \\
\text { de costas para } \\
\text { Marcela) })\end{array}$ & $\begin{array}{l}13 \text { - Lúcio se dispersa } \\
\text { quando a colega fala. }\end{array}$ \\
\hline
\end{tabular}

(continua...) 
(...continuação)

\begin{tabular}{|c|c|c|c|c|}
\hline Linhas & Professora & Crianças & & Comentários \\
\hline 66 & & entra num negócio onde & $\begin{array}{l}\text { ((Carlos se } \\
\text { levanta em } \\
\text { direção à } \\
\text { Paula e olha } \\
\text { o livro em } \\
\text { suas mãos. } \\
\text { A seguir, } \\
\text { olha para } \\
\text { Marcela)) }\end{array}$ & $\begin{array}{l}14 \text { - Carlos se interessa } \\
\text { em ver a página que Paula } \\
\text { está lendo para o grupo. }\end{array}$ \\
\hline 67 & & ele deita & & \\
\hline 68 & & joga a bola & & \\
\hline 69 & & ai esconde & & \\
\hline 70 & $\begin{array}{l}\text { você viu lá na } \\
\text { sua casa? }\end{array}$ & & & $\begin{array}{l}15 \text { - Paula mostra-se } \\
\text { interessada no que } \\
\text { Marcela compartilha. }\end{array}$ \\
\hline 71 & $\begin{array}{l}\text { depois eu quero } \\
\text { entender }\end{array}$ & & & \\
\hline 72 & $\begin{array}{l}\text { ((começa a se } \\
\text { levantar) })\end{array}$ & $(($ Crianças se levantam $))$ & & $\begin{array}{l}16 \text { - Crianças acompanham } \\
\text { o movimento da professora. }\end{array}$ \\
\hline 73 & bom & & & \\
\hline 74 & $\begin{array}{l}\text { eu vou ser o } \\
\text { pegador primeiro }\end{array}$ & & & $\begin{array}{l}17 \text { - Paula se inclui } \\
\text { na brincadeira. }\end{array}$ \\
\hline 75 & $\begin{array}{l}\text { pra gente poder } \\
\text { entender essa } \\
\text { brincadeira }\end{array}$ & $\begin{array}{l}\text { Lúcio: ah não/ } \\
\text { essa brincadeira } \\
\text { é muito chata }\end{array}$ & & $\begin{array}{l}18 \text { - Lúcio se recusa a } \\
\text { participar da brincadeira } \\
\text { com o grupo e senta-se } \\
\text { na escada do pátio. }\end{array}$ \\
\hline 76 & $\begin{array}{l}\text { todo mundo lá } \\
\text { ((apontando o } \\
\text { pátio azul }))\end{array}$ & & & \\
\hline 77 & pertinho de mim & & & \\
\hline 78 & & $\begin{array}{l}\text { ((Crianças correm para } \\
\text { o pátio azul e sobem } \\
\text { no banco de cimento }) \text { ) }\end{array}$ & & $\begin{array}{l}19 \text { - Transição para } \\
\text { a brincadeira. }\end{array}$ \\
\hline 79 & não & & & \\
\hline 80 & $\begin{array}{l}\text { ((anda em direção } \\
\text { ao meio do pátio, } \\
\text { estende as mãos }))\end{array}$ & & & \\
\hline 81 & aqui & & & \\
\hline 82 & pertinho & $\begin{array}{l}((\text { Crianças se agrupam } \\
\text { ao redor de Paula }))\end{array}$ & & \\
\hline
\end{tabular}

Fonte: Banco de dados da pesquisa.

Elaboração das autoras.

disciplina foi trabalhada como condição de desenvolvimento das atividades, e não como exigência de um "bom" comportamento.

Salientamos que o silêncio das crianças deveu-se a uma escuta ativa da leitura feita pela professora: elas mostraram-se absolutamente interessadas na atividade proposta. Entendemos que esse interesse deve-se (a) ao objetivo explícito da atividade, 


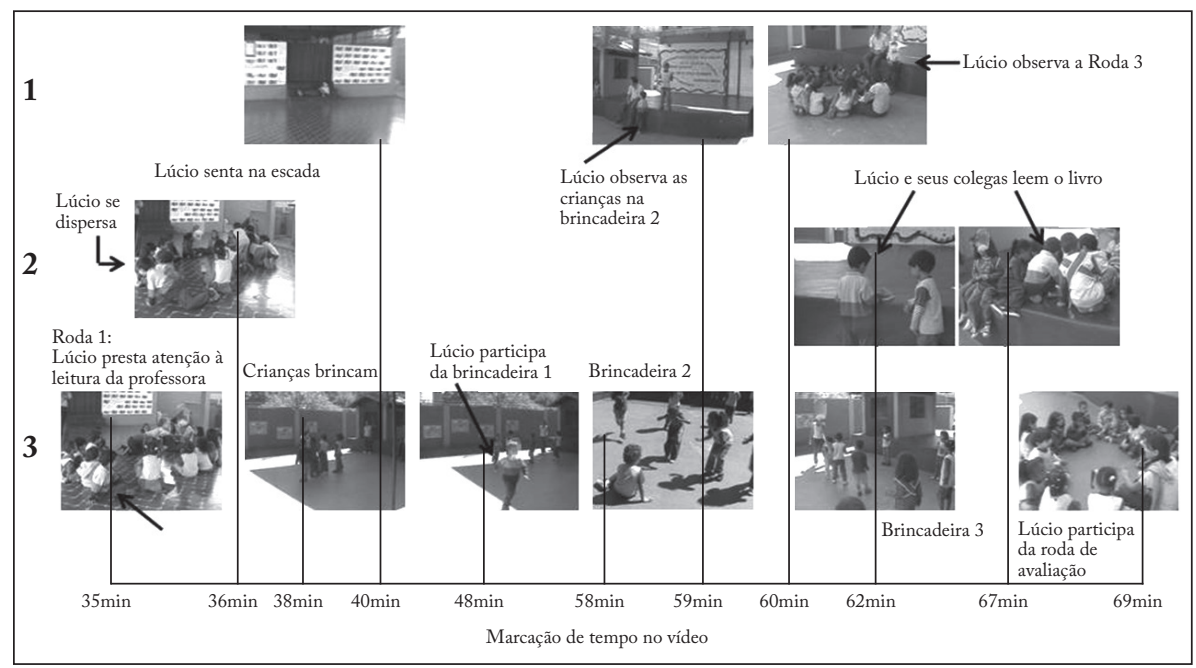

Figura 3 - A participação de Lúcio ao longo do evento "Brincadeiras diferentes". Fonte: Banco de dados da pesquisa.

Elaboração das autoras.

anunciado por Paula ao grupo ainda no momento do calendário (Quadro 1); (b) à curiosidade das crianças em ver a professora lendo (linhas 7, 11, 23, 35 e 66); (c) à leitura sobre um tema, brincadeiras, muito próximo da cultura e da história do grupo; (d) ao envolvimento da professora na atividade ao se incluir na brincadeira (eu achei umal que é muito legal - linhas 13 e 14; vamos tentar brincar disso? - linha 62); e (e) ao curto tempo de duração da roda, dois minutos, o que manteve a capacidade de concentração do grupo em um nível máximo.

O envolvimento de Lúcio na Roda 1 destoou do interesse demonstrado pelos colegas, possibilitando um contraste com o que foi esperado do grupo ao longo desse evento, como podemos verificar com a análise da Figura 3. As fotografias inseridas nessa figura foram criadas por meio da gravação em vídeo do evento e registram as ações desenvolvidas por Lúcio. As linhas 2 e 3 apresentam a sequência de suas ações, em contraste com as ações das outras crianças, na linha 1. Em uma linha do tempo, apresentamos a marcação dos minutos, ligando-os aos quadros do vídeo.

Lúcio inicia a roda sentando-se de lado, olhando e mexendo em seu tênis. Olha para Paula quando ela começa a leitura (35 minutos), se dispersa quando ela chama a atenção de Marcela e Taís (36 minutos), olha novamente para a professora e, ao final, rejeita a proposta de brincar: ah nãol essa brincadeira é muito chata (linha 75 , Quadro 2). Lúcio senta na escada (40 minutos) e, após oito minutos, decide participar da primeira brincadeira. Ao longo das segunda e terceira brincadeiras, Lúcio posiciona-se como observador (59 minutos). Finalmente, Lúcio propõe uma nova forma de participação no evento: ele folheia o livro de brincadeiras com alguns colegas (62 minutos e 67 minutos). Paula aceitou essa forma de participação, não exigindo que Lúcio integrasse o grupo que realizava a brincadeira. 
Em relação à primeira brincadeira, salientaremos elementos relacionados à maneira como a professora interagiu com a turma. Paula, de fato, brincou com as crianças, sendo o pegador e, depois, juntando-se ao grupo que corria para não ser pego. Seu envolvimento com as brincadeiras no pátio foi percebido pelas crianças. No dia 27 de agosto de 2008, na oficina de artes, a pesquisadora conversou sobre a escola com uma das crianças da turma, Miriam. Na apresentação de um trecho dessa entrevista, destacamos em negrito as falas de Miriam relacionadas ao envolvimento da professora com a turma.

$[\ldots]$

Pesquisadora: éé/ me diz uma coisa/ Miriam/ cê vem na escola todo dia?

Miriam: ((balança a cabeça afirmativamente)

Pesquisadora: é?

Miriam: $\quad$ Por que tem que estudar/ né?

Pesquisadora: estudar?

Miriam: é

Pesquisadora: que que cê estuda aqui?

Miriam: $\quad$ humm/ não quero estudar aqui (Ela fala muito baixo. Só escutamos essa fala ao fazer a transcrição)

Pesquisadora: ée?/que que cêe estuda aqui / na escola?

Miriam: oquê?

Pesquisadora: $\quad e ́$

Miriam: que que eu estudo aqui na escola?

Pesquisadora: é

Miriam:

Pesquisadora: $e^{e} ?$

Miriam:

Pesquisadora: éê/e desse montão de coisa que você faz aqui/ que que você mais gosta?

Miriam: De:::/ brincar com a Paula.

Pesquisadora: éêle que que cês brincam?

Miriam: a gente brinca:::/a::: gente/ brinca lá no pátio/de pega-pegal de tartaruga/leão dorminhoco

Pesquisadora: Ab:::/ isso é legal/ né?

Miriam: ((balança a cabeça afirmativamente))

Pesquisadora: e dessas coisas que cê faz aquil tem alguma coisa que você não gosta?

Miriam: $\quad$ TEM

Pesquisadora: oquê?

Miriam: $\quad$ ir no recreio

Pesquisadora: cênão GOSTA/ de ir no recreio?

Miriam: (balança a cabeça negativamente))

Pesquisadora: por quê?

Miriam: $\quad$ porque no recreiol todo mundo machuca e eu tenho dó

$[\ldots]$ 
$\mathrm{Na}$ entrevista com Miriam, evidencia-se o envolvimento da professora com as crianças nos momentos de brincadeiras e como esse fato é apropriado afetivamente pela criança. Miriam diz que o que mais gosta na escola é brincar com Paula: "a::: gente brinca lá no pátio/ de pega-pega" . ${ }^{7}$ A questão que se apresenta para análise não é apenas a brincadeira em si, mas a presença efetiva do adulto nos momentos de brincar.

Nesse sentido, Miriam afirma, para nossa surpresa, que o recreio é o momento de que ela menos gosta na escola. De fato, o recreio caracterizou-se pelo pouco envolvimento dos adultos com as crianças. A intervenção dos adultos aconteceu apenas nos momentos de conflito entre as crianças. Assim, o recreio perdeu a intencionalidade educativa percebida em outros momentos institucionais, ou seja, a ausência de mediação da professora possibilitou a emergência de conflitos que provocaram insegurança na criança. Corsaro (2005) analisa como, nas negociações de amizade na cultura de pares infantil, os conflitos constituem dimensão presente, muitas vezes resolvidos corporalmente. A fala da criança revela uma posição de retraimento perante tais negociações, posição comum na vivência cotidiana do grupo de pares.

Destacamos o fato de que Miriam disse que estuda na escola, e mais, ela estuda palavras. No momento da entrevista, a pesquisadora não explorou essa expressão e o que ela significaria para Miriam. Seriam as palavras faladas? Seriam as palavras escritas? Ao longo do trabalho de campo, foi ficando cada vez mais claro o enorme interesse que as crianças nutriam pela escrita. No evento "Brincadeiras diferentes", esse interesse foi evidenciado, por exemplo, nos momentos de leitura das instruções das brincadeiras pela professora (Quadro 2) e na leitura do livro realizada por Lúcio e seus colegas (Figura 3 ).

Lúcio e Bruno apontaram as páginas do livro e olharam um para o outro (Figura 3; 62 minutos). Um minuto depois, Luiz e Wanda juntaram-se a eles na leitura do livro. A gravação em vídeo permite escutar Bruno dizendo "acorda urso/ acorda urso", enquanto apontava uma página do livro. Supomos, então, que as crianças procuravam localizar brincadeiras nas páginas do livro. Ao escutar Bruno, Carlos parou de brincar e aproximou-se. A seguir, uma nova rodada da brincadeira cabra-cega começou. Carlos e Wanda afastaram-se e começaram a brincar, ao passo que Antônio se aproximou do grupo que lia. Paula, percebendo que as crianças estavam envolvidas com o livro, pediu que eles subissem no palco para continuar a leitura. Um minuto depois, já eram seis crianças ao redor do livro (Figura 2; 67 minutos).

É perceptível como esse livro provocou o interesse do grupo, desde o momento da primeira roda. Tal interesse se relaciona com a possibilidade de as crianças associarem o vivido com o escrito e identificarem no texto aquilo que já conheciam. As crianças introduziram uma nova atividade, a leitura do livro, e a professora reconheceu como legítima a modificação proposta por elas. As crianças, por meio de suas interações, ativamente criaram novos significados para a brincadeira no pátio,

7 A surpresa da professora ao ser lembrada pelo porteiro da escola que já estava na hora da saída, ao final do evento "Brincadeiras diferentes", pode ser tomada como evidência de seu envolvimento nas brincadeiras e rodas de conversa com as crianças e dota de significado a expressão usada por Miriam. Tal envolvimento nos possibilita compreender a afirmação de que Miriam gosta de brincar com Paula. 
transformando-a também em um evento de letramento. Criativamente, elas integraram as brincadeiras típicas da cultura escolar daquela instituição e a apropriação da linguagem escrita, construindo uma cultura de pares marcada por um "brincar letrando". ${ }^{8}$ Portanto, o diferente nesse evento não se limitou apenas à aprendizagem das novas brincadeiras, conforme havia sido anunciado pela professora, posto que, interessadas pela linguagem escrita, as crianças criaram outras oportunidades de aprendizagem (Tuyay et al., 1995) para si e para os outros ao buscarem desvelar os significados da escrita.

Ao final da brincadeira, Paula pediu que as crianças fizessem uma nova roda. A professora relembrou com as crianças as brincadeiras que fizeram e perguntou o que o grupo achou dessas brincadeiras:

\begin{tabular}{|c|c|}
\hline Paula: & $\begin{array}{l}\text { agora cada um vai falar/ quem quiser/vai falar } \\
{[\ldots . .]}\end{array}$ \\
\hline Marcela: & eu/ eu gostei de todas \\
\hline Carlos: & ((balança o corpo)) \\
\hline Paula: & $\begin{array}{l}\text { Carlos:::/ ((olhando para Carlos)) quando você/ falou/ as pessoas } \\
\text { pararam e ouviram/((olha para Lúcio))/ o::: Lúcio/ vo/você gos- } \\
\text { tou de tudo?/ ou não?/ }\end{array}$ \\
\hline Lúcio: & gostei/ da acorda senhor urso \\
\hline Paula: & acorda senhor urso?/ e você participou? \\
\hline Lúcio: & ((balança a cabeça afirmativamente) $)$ \\
\hline Paula: & $\begin{array}{l}\text { foị/ e:::/ o que você NÃO/ gostou?/ ((olha para as crianças)) } \\
\text { vamos ouvir o colega/ qual brincadeira/ você NÃO/ participou?/ }\end{array}$ \\
\hline Carlos: & nenhuma das duas \\
\hline Paula: & qual brincadeira/ você não participou?/ \\
\hline Carlos: & acorda senhor urso \\
\hline Lúcio: & eu participei de duas ((mostra dois dedos da mão)) \\
\hline Paula: & qual você participou? \\
\hline Lúcio: & acorda senhor urso \\
\hline Paula: & você participou/ do alerta 123 ? \\
\hline Lúcio: & ((balança a cabeça negativamente, de forma muito lenta)) \\
\hline Paula: & você participou/ do cabra-cega? \\
\hline Lúcio: & ((balança a cabeça negativamente, olhando para o chão)) \\
\hline Paula: & por que não? \\
\hline Lúcio: & eu não gosto \\
\hline Paula: & por que você/ não gosta? \\
\hline Lúcio: & ((balança as mãos, fechando os olhos)) \\
\hline
\end{tabular}

8 Fazemos aqui uma paráfrase de Magda Soares (1999). A autora desenvolve reflexões teóricas acerca da importância de "alfabetizar letrando" ao longo do processo de apropriação da linguagem escrita. 
Paula: não sabe?/ você vai pensar/ o que você/ não gosta/ pra você/ me contar/ tá?/ alguém mais?

Paula: o Gilberto/vai falar/ gente

Porteiro: ((aproximando-se da roda)) vou abrir o portão

Professora: especial/ JÁ:::? ((começa a se levantar))

Gilberto: $\quad$ eu gostei de todas

Professora: já abriu/ gente/ mas aqui/ sem correria

Crianças: ((levantam-se e andam atrás da professora))

Durante essa roda, Paula pediu uma avaliação das atividades desenvolvidas no evento "Brincadeiras diferentes". Conforme pode ser visto na transcrição anterior, essa avaliação recaiu sobre as brincadeiras (se as crianças gostaram das brincadeiras, se e como haviam participado delas). Paula, ao voltar-se para Lúcio, explicita para o grupo como foi sua participação durante o evento, aceitando sua resposta, mas o desafiando a produzir uma justificativa para o seu não gostar de determinadas brincadeiras. Aqui fica claro que a participação diferenciada de Lúcio na atividade foi permitida, mas não foi aquela esperada pelo grupo.

A análise dessa conversa entre professora e seus alunos nos permite ver, por um lado, como a roda de conversa constituiu-se como uma rotina cultural da turma pesquisada, reafirmando o pertencimento dos membros ao grupo ao dar visibilidade às suas ações, falas, relações de amizade e suas atividades ao longo dos dias. Por outro lado, nos permite ver também como a participação das crianças nas rodas de leitura, o interesse daquelas pela escrita e a ação de Lúcio e seus colegas de explorar e ler o livro juntos não foi abordada nas perguntas que a professora dirige à turma. $\mathrm{Ou}$ seja, nesse caso, como em outros momentos observados ao longo do ano, as ações letradas desenvolvidas pelos participantes (alunos e professora) não foram foco da conversa como objeto de reflexão.

Assim, a prática social de leitura de um livro não foi explicitamente considerada e avaliada pelo grupo. Nesse sentido, observa-se que, se o objeto livro é parte integrante da cultura material da escola, não constitui objeto de conhecimento privilegiado nos momentos de reflexão sobre as ações e atividades do grupo. Como outros artefatos da cultura material infantil, o livro torna-se objeto de apropriação da cultura adulta e da cultura de pares (Corsaro, 2005) pela criança, embora esse significado tenha sido pouco trabalhado pela professora.

$\mathrm{Na}$ seção seguinte, buscamos explicitar uma articulação possível entre o brincar, as práticas de letramento evidenciada pela cultura de pares aqui analisada e suas implicações para as discussões recentes sobre o lugar do letramento na educação infantil.

\section{AMPLIANDO NOSSO OLHAR}

Evidenciamos ao longo deste texto que, ao mesmo tempo em que houve uma estruturação das atividades pedagógicas pelas professoras ao longo do ano, foi possível às crianças participar de maneiras diferenciadas dentro de um conjunto de 
opções oferecido ao grupo. A socialização das crianças no ambiente dessa escola de educação infantil thes permitiu coordenar as próprias vontades e desejos com as expectativas e demandas estabelecidas nesse espaço institucional por participantes do grupo (por exemplo, professora e alunos, coordenadores e outros). Nesse movimento, articulando o individual e o coletivo (Gaskins; Miller; Corsaro, 1992), as crianças constituíram-se como membros dessa turma. Duas das práticas sociais estabelecidas pelo grupo (a roda de conversa e o brincar) estão presentes no discurso do campo da educação infantil, tanto em documentos oficiais quanto nas formações de professores propostas pela Secretaria Municipal de Educação de Belo Horizonte. Assim, as práticas educativas das professoras não são apenas escolhas pessoais, mas se referem também ao campo discursivo da educação.

Consideramos necessário ampliar a discussão sobre o discurso do brincar no que se refere à sua predominância na educação infantil. Pensando com Foucault (1986), perguntamos: O que esse discurso inclui e o que ele exclui? Sarah Mills (1997, p. 16-17, tradução nossa) nos esclarece:

[A verdade] é algo que as sociedades têm trabalhado muito para produzir, ao invés de ser algo que aparece de maneira transcendental. [...] Portanto, discursos não existem em um vácuo, mas estão em constante conflito com outros discursos e outras práticas sociais que os influenciam acerca de questões da verdade e da autoridade.

Essa discussão é fundamental por nos sugerir que a importância do brincar na educação infantil tem raízes históricas, não se restringindo ao contexto específico dessa sala de aula. A construção simbólica de um discurso educacional no qual o brincar é central na educação infantil tem tido grande aceitação por parte dos acadêmicos brasileiros. Baseando-se nos trabalhos de vários autores (Benjamin, 1984; Brougère, 1994; Huizinga, 1980; Piaget, 1991; Vigotski, 2008, entre outros), o brincar tem sido considerado por pesquisadores, gestores públicos e vários educadores como a principal linguagem que as crianças usam tanto para se apropriar do mundo quanto para se expressar. De maneira resumida, pode-se afirmar que o brincar possibilita à criança o poder de tomar decisões, de expressar sentimentos e valores, de conhecer a si, aos outros e ao mundo, de repetir ações prazerosas, de elaborar conflitos, de partilhar significados e de desenvolver o pensamento abstrato, bem como de desenvolver habilidades ainda não consolidadas.

Assim, a produção do conhecimento e de discursos pedagógicos sobre o brincar tem como grande mérito trazer as crianças e suas culturas para o centro da prática pedagógica da educação infantil. Da mesma maneira, o discurso do brincar desafiou a "pedagogia da submissão" voltada ao disciplinamento das crianças (Kuhlmann Júnior, 1998), bem como questionou o uso de atividades de aprendizado da língua escrita, fundadas no treinamento perceptual e psicomotor, nas práticas educativas da primeira etapa da educação básica, rejeitando a perspectiva da educação infantil como preparação das crianças para o ensino fundamental.

Contudo, o discurso do brincar, quando mal compreendido, deixou em segundo plano a discussão sobre o interesse das crianças pela língua escrita. As crianças 
são sujeitos sociais que, ao longo dos processos de desenvolvimento individual, apropriam-se dos sistemas simbólicos da cultura na qual estão inseridas. À medida que a cultura escrita constitui, nas sociedades letradas contemporâneas, importante mediador das relações sociais, o processo de participação na cultura passa pelo domínio desse mediador, informando o desejo da criança pela sua aquisição. Assim é que a inclusão das crianças em nossa sociedade remete ao processo de letramento, com todas as implicações que isso acarreta. Tal discussão não pode estar ausente do campo da educação infantil, uma vez que o processo de escolarização (mesmo que com características diferenciadas em cada etapa educacional) de um número cada vez maior de crianças, de todas as classes sociais, começa aos 4 anos.

Não podemos também esquecer as relações de poder que estão implicadas no uso da linguagem escrita. A criança, por meio da participação nas atividades sociais intergeracionais, percebe que o domínio da língua escrita confere ao adulto um saber que determina um lugar de poder, ao qual ela quer ter acesso. Tal aspecto foi evidenciado nas análises apresentadas anteriormente, em que vimos como as crianças ativamente (re)criaram possibilidades de engajamento com a leitura e a escrita. De certa maneira, a ação das crianças nesse contexto nos leva a compreender que, para elas, a dicotomia entre o brincar e práticas de letramento significativas não existe. As crianças estabelecem um movimento que atenua fronteiras entre $o$ ler, o escrever e o brincar.

É necessário, da mesma maneira, considerar o quadro amplo da educação básica brasileira. No campo da educação infantil, uma maior discussão acerca da alfabetização e do letramento acontece de maneira dicotômica, como bem observa Campos (2009, p. 13):

No campo da Educação Infantil, podemos observar duas posições extremas. De um lado, muitas pré-escolas forçam uma alfabetização a crianças muito novas, sem respeitar os ritmos individuais e as características da faixa etária. De outro lado, prospera uma visão romantizada do desenvolvimento infantil, que rejeita qualquer programação que inclua material escrito, entendida como escolarização precoce, privando as crianças mais pobres daquelas experiências de que não dispõem em seus ambientes familiares.

Sem dúvida, essas são questões fundamentais que provocam um debate necessário para a formação inicial e continuada de professoras, e também para o campo das políticas educacionais. ${ }^{9} \mathrm{~A}$ análise do evento "Brincadeiras diferentes" possibilitou, por meio da observação da professora e das crianças lendo e brincando,

9 Nesse contexto, houve o estabelecimento de uma parceria e financiamento do Ministério da Educação com as Universidade Federal de Minas Gerais (UFMG), Universidade Federal do Rio de Janeiro (UFRJ) e Universidade Federal do Estado do Rio de Janeiro (UNIRIO) na concepção e execução do Projeto Leitura e Escrita na Educação Infantil. Tal projeto tem como um de seus objetivos contribuir para o fortalecimento da identidade da educação infantil, especialmente no que se refere ao seu lugar na formação de leitores. 
questionar essa dicotomia. Se, para os adultos, as atividades do brincar diferenciam-se do alfabetizar pelo seu caráter sistemático, pode-se observar que, para as crianças, tal dicotomia não se mostra tão evidente. $O$ desejo de domínio da língua escrita faz com que a criança atribua um sentido lúdico às complexas atividades de seu aprendizado.

Cabe retomar, para melhor entender essa questão, as argutas observações sobre o brincar desenvolvidos por Freud (1969) no texto "Além do princípio do prazer". Ao analisar as teorias da época que afirmavam que o sentido do brincar para a criança era o prazer derivado de sua execução, Freud observou que o tema das brincadeiras infantis era muitas vezes a elaboração simbólica de situações dolorosas. Assim é que a psicanálise ajuda-nos a entender que o brincar envolve dimensões mais complexas que o prazer imediato em sua execução, que a criança brinca também com aquilo que a angustia, de forma a significar a experiência.

Nesse sentido, atividades de letramento, mesmo que envolvam um esforço em sua execução, têm para a criança uma dimensão lúdica, ao introduzi-la no mundo da escrita, objeto de seu desejo. No dia a dia, a separação entre brincar e alfabetizar é atenuada: quando as crianças estão lendo o livro, não estariam elas também brincando? Isto é, no evento analisado, a atividade de leitura tornou-se tão fundamental para o grupo quanto a atividade de brincar, atendendo às necessidades infantis e propiciando o desenvolvimento cultural das crianças (Vigotski, 2008).

Poderíamos argumentar que a possibilidade de observar uma brincadeira do grupo e, paralelamente, ocupar-se de outras coisas (ler/folhear livro sobre brincadeira) favorece o desenvolvimento da autonomia e da capacidade de fazer escolhas (Lúcio não é obrigado a fazer tudo do mesmo jeito que todo o grupo) e de estabelecer conexões temáticas (permanecer em uma atividade relacionada ao que a maioria está fazendo). O livro torna-se "brinquedo": a exploração é livre, com constituição e dissolução de significados, bem como com mudança de parceiros, como se vê comumente em outras brincadeiras.

Ao aproximarmos as atividades de brincadeira, leitura e escrita, tomamos como referência o significado dessas ações para a criança, de forma a superar sua aparente dicotomia e possibilitar a condução dos trabalhos na educação infantil que tornem possível o brincar letrando e alfabetizando. A distinção e polarização entre tais termos, definindo o brincar como característico da criança pequena, a ser desenvolvido na educação infantil, contraposto ao alfabetizar, entendido como trabalho sistemático de apropriação da língua escrita, prática restrita ao ensino fundamental, não se expressa na ação da criança. A criança, ao mesmo tempo em que empresta um sentido lúdico às práticas de letramento que se fazem presentes na educação infantil, demanda um trabalho mais sistemático com a língua escrita, investindo-a de uma dimensão lúdica.

Por outro lado, as práticas de escrita, ao mesmo tempo em que se diferenciam do desenho, têm para a criança uma continuidade. Desenhar-se, desenhar sua experiência, escrever o próprio nome ou as palavras que dão forma ao vivido têm para a criança o sentido de inscrever-se no mundo, deixando marcas de sua experiência subjetiva. Em ambas se expressa um caráter lúdico em sua execução. 
Defendemos que é possível e necessária a construção de uma prática pedagógica que respeite as culturas de pares e o desenvolvimento infantil, integrando o brincar e a construção do conhecimento, mais especificamente a apropriação da linguagem escrita, em direção a um "brincar letrando" ou a um "letrar brincando" na educação infantil e no ensino fundamental. Essa integração possibilitaria a construção de um "lugar de encontro pedagógico" (Moss, 2008, p. 229) entre as duas primeiras etapas da educação básica.

\section{REFERÊNCIAS}

Baptista, M. C. Alfabetização e letramento em classes de crianças menores de sete anos. In: FrADe, I. C. A. et al. (Org.). Convergências e tensões no campo da formação e do trabalho docente. Belo Horizonte: Autêntica, 2010.

Barbosa, M. C. S. Culturas escolares, culturas de infância e culturas familiares: as socializações e a escolarização no entretecer destas culturas. Educação e Sociedade, Campinas: CEDES, v. 28, p. 1.059-1.083, especial 2007.

Benjamin, W. Reflexões: a criança, o brinquedo, a educação. São Paulo: Summus, 1984. Brandão, A. C. P.; Rosa, E. C. S. (Orgs.). Ler e escrever na educação infantil. Belo Horizonte: Autêntica, 2010.

Brasil. Ministério da Educação. Secretaria de Educação Básica. Programa Currículo em Movimento. Brasília, DF, 2009. Disponível em: <http://portal.mec.gov.br/index. php?option=com_content\&view=article\&id=15860\&Itemid=1096>. Acesso em: 12 mar. 2012.

Bor ba, Â. Culturas da infância nos espaços-tempos do brincar. 2005. Tese (Doutorado em Educação) - Universidade Federal Fluminense, Niterói, 2005.

Brougère, G. Brinquedo e cultura. São Paulo: Cortez, 1994.

Campos, M. M. A formação de professores para crianças de 0 a 10 anos: modelos em debate. Educação E Sociedade, Campinas: CEDES, v. 68, p. 126-142, 1999.

Ensino fundamental e os desafios da lei n. 11.274/2006. In: BrasiL. Salto para o futuro. Anos iniciais do ensino fundamental. Brasília, DF: Secretaria de Educação a Distância; Ministério da Educação, 2009.

Castanheira, M. L. Entrada na escola, saída da escrita. 1991. Dissertação (Mestrado em Educação) - Universidade Federal de Minas Gerais, Belo Horizonte, 1991.

. Aprendizagem contextualizada: discursos e inclusão na sala de aula. Belo Horizonte: CEALE; Autêntica, 2004.

; Crawford, T.; Dixon, C.; Green,J. Interactional ethnography: an approach to studying the social construction of literate practices. Linguistics and Education, Nashville: Elsevier, v. 11, n. 4, p. 353-400, 2001.

; Green, J.; Dixon, C. Práticas de letramento em sala de aula: uma análise de ações letradas como construção social. Revista Portuguesa de Educação, Braga: Universidade do Minho, v. 20, n. 2, p. 7-38, 2007. 
; Neves, V. F. A.; GouvêA, M. C. S. Eventos interacionais e eventos de letramento: um exame das condições sociais e semióticas da escrita em uma turma de educação infantil. Cadernos CEDES, Campinas: CEDES, v. 33, n. 89, p. 91-107, 2013. Corsaro, W. Interpretive reproduction in children's peer cultures. Social Psychology Quarterly, Washington, DC: Sage, v. 55, n. 2, p. 160-177, 1992.

The sociology of childhood. 2. ed. London: Sage Publications, 2005.

; Molinari, L. I compagni: understanding children's transition from preschool to elementary school. New York: Teachers College Press, 2005.

; NeLson, E. Children's collective activities and peer culture in early literacy in american and italian preschools. Sociology of Education, Washington, DC: Sage, v. 76, p. 209-227, jul. 2003.

Corsino, P. Infância, educação infantil e letramento na rede municipal de ensino do Rio de Janeiro: das políticas à sala de aula. In: Reunião Anual da Associação Nacional de Pós-Graduação e Pesquisa em Educação, 28., 2005, Caxambu. Anais... Caxambu: ANPEd, 2005.

Соoк-Gumperz, J. A construção social da alfabetização. Porto Alegre: Artmed, 1991. Dixon, C.; Green, J. Studying the discursive construction of texts in classrooms through interactional ethnography. In: $\mathrm{BEACH}, \mathrm{R}$. et al. Multidisciplinary perspectives on literacy research. New Jersey: Hampton Press, 2005.

Faria Filho, L. M.; Gonçalves, J. A.; Vidal, D. G.; Paulilo, A. L. A cultura escolar como categoria de análise e campo de investigação na história da educação brasileira. Educação e Pesquisa, São Paulo: Faculdade de Educação da Universidade de São Paulo, v. 30, n. 1, p. 139-159, 2004.

Foucault, M. Microfísica do poder. 6. ed. Rio de Janeiro: Graal, 1986.

Freud, S. Além do princípio do prazer. In: SIGMUND FREUD. Obra completa. Rio de Janeiro: Imago, [1920] 1969. (Edição Standard das Obras psicológicas completas de Sigmund Freud, v. XVIII)

Gaskins, S.; Miller, P.J.; Corsaro, W. Theoretical and methodological perspectives in the interpretive study of children. In: Corsaro, W.; Miller, P. J. (Orgs.). Interpretive approaches to children's socialization. San Francisco: New Directions for Child Development, 1992.

Gerde, H. K.; Bingham, G. E.; Wasik, B. A. Writing in early childhood classrooms: guidance for best practices. Early Childhood Educational Journal, Netherlands: Spinger, v. 40, n. 6, p. 351-359, 2012.

Gilmore, P.; Glatthorn, A. Children in and out of school. New York: Ablex Publishing, 1987.

Green, J.; Dixon, C.; Zaharlick, A. A etnografia como uma lógica de investigação. Educação em Revista, Belo Horizonte: Programa de Pós-Graduação da Faculdade de Educação da Universidade Federal de Minas Gerais, n. 42, p. 13-79, dez. 2005.

Gumperz, J. (Ed.). Language and social identity. New York: Cambridge University Press, 1982. 
Heath, S. B. Ways with words: language, life, and work in communities and classrooms. New York: Cambridge University Press, 1983.

Hicks, D. Discourse, learning and teaching. Review of Research in Education, Washington, DC: Sage, v. 21, p. 49-95, 1995.

Huizinga, J. Homo ludens: o jogo como elemento da cultura. 2. ed. São Paulo: Perspectiva, 1980.

Kramer, S. O papel da educação infantil na formação do leitor: descompassos entre as políticas, as práticas e a produção acadêmica. In: Frade, I. C. A. et al. (Orgs.). Convergências e tensões no campo da formação e do trabalho docente. Belo Horizonte: Autêntica, 2010.

Kress, G. Before writing: rethinking the paths to literacy. London: Routledge, 1997.

Kuhlmann Júnior, M. Infância e educação infantil: uma abordagem histórica. Porto Alegre: Mediação, 1998.

Mills, S. Discourse. London; New York: Routledge, 1997.

Mitchell, J. C. Case studies. In: Ellen, R. F. Ethnographic research: a guide to general conduct. Orlando: Academic Press, 1984.

Moss, P. What future for the relationship between early childhood education and care and compulsory schooling? Research in Comparative and International Education, Oxford: Symposium Journals, v. 3, n. 3, p. 224-234, 2008.

Neves, V. F. A.; Gouvêa, M. C. S.; Castanheira, M. L. A passagem da educação infantil para o ensino fundamental: tensões contemporâneas. Educação e Pesquisa, São Paulo, Faculdade de Educação da Universidade de São Paulo, v. 37, n. 1, p. 121-140, 2011.

Nogueira, G. M. A passagem da educação infantil para o $1^{\circ}$ ano no contexto do ensino fundamental de nove anos: um estudo sobre alfabetização, letramento e cultura lúdica. 2011. Tese (Doutorado em Educação) - Universidade Federal de Pelotas, Pelotas, 2011.

Packer, M. J.; Goicoechea, J. Sociocultural and constructivist theories of learning: ontology, just not epistemology. Educational Psychologist, Washington, DC: Lawrence Erlbaum, v. 35, n. 94, p. 227-241, 2000.

Piaget, J. Seis estudos de psicologia. São Paulo: Forense, 1991.

Soares, M. Letramento: um tema em três gêneros. Belo Horizonte: Autêntica, 1999.

Street, B. Literacy in theory and practice. Cambridge: Cambridge University Press, 1984. .What's "new" in New Literacy Studies? Critical approaches to literacy in theory and practice. Current Issues in Comparative Education, New York: Columbia University, v. 5, n. 2, p. 77-91, 2003.

Tuyay, S.; Floriani, A.; Yeager, B.; Dixon, C. N.; Green, J. L. Constructing an integrated, inquiry-oriented approach in classrooms: a cross-case analysis of social, literate, and academic practice. Journal of Classroom Interaction, Houston: University of Houston, v. 30, n. 2, p. 1-15, 1995.

Vigotski, L. S. A brincadeira e o seu papel no desenvolvimento psíquico da criança. Revista Virtual GIS, Rio de Janeiro: Laboratório de Tecnologia e Desenvolvimento Social, UFRJ, [1933] 2008. 
Wajsкор, G. O brincar na educação infantil. Cadernos de Pesquisa, São Paulo: Fundação Carlos Chagas; Campinas: Autores Associados, v. 92, p. 62-69, fev. 1995.

\section{SOBRE AS AUTORAS}

Vanessa Ferraz Almeida Neves é doutora em educação pela Universidade Federal de Minas Gerais (UFMG). Professora da mesma instituição.

E-mail:vfaneves@gmail.com

Maria Lúcia Castanheira é doutora em filosofia da educação pela University of California Santa Barbara (Estados Unidos). Professora da Universidade Federal de Minas Gerais (UFMG).

E-mail:1alucia@gmail.com

Maria Cristina Soares Gouvêa é doutora em educação pela Universidade Federal de Minas Gerais (UFMG). Professora da mesma instituição.

E-mail: crisoares43@yahoo.com.br

Recebido em junbo de 2012

Aprovado em maio de 2014 